\author{
Magdalena Mruszczyk \\ Uniwersytet Śląski w Katowicach \\ (D) https://orcid.org/0000-0002-4025-0536
}

\title{
Filozofia życia Anny-Teresy Tymienieckiej i zagadnienie Boga
}

\section{Anna-Teresa Tymieniecka's Philosophy of Life and the Question of God}

\begin{abstract}
Anna-Teresa Tymieniecka's philosophy of life of is a phenomenological vision of the self-development of the human spirit presented from a cosmological perspective and in the formula of self-individualization of man in existence and at the same time his selfinterpretation in life. This development cannot be realized solely on the basis of reason, through the subject's cognitive act. For the self-interpretation of man in existence, his creative act is necessary, one which expresses the creative operation of the human imagination. It is this path of the human mind's self-tracking which sees its sources in the first, pre-organic processes of the formation of the universe. These processes evolved towards the attainment of an ever higher degree of complexity in the living forms of nature, up to the form of human self-awareness expressed in man's creative act and in the realization by the human spirit of its transnatural vocation. Man's aspiration to fulfill his life's destiny takes place in three steps (or "movements of the soul"): intellectual, socio-moral, and sacred. Their description in the phenomenology of life emerges from a metaphysical and at once existentialist vision of human life as being in-unity-with-all-that-lives. We can say that this vision is the starting point of Tymieniecka's phenomenology of life and of the human creative condition. Arguably, in her theory, the most important thing is to follow the sacred path of life's logos in order to attain communion with the Divine (God, the Sacred, the Transcendent, the Unconditioned, the All-Encompassing). On this path, the phenomenology of the human spirit attains completion and phenomenology - phenomenology.

Keywords: logos of life, imagination, Great Metamorphosis, soul, Transcendence
\end{abstract}




\section{Wstęp}

Anna-Teresa Tymieniecka (1923-2014) budowała swoją koncepcję filozofii życia przez ponad czterdzieści lat pracy naukowej ${ }^{1}$. Te cztery dekady uwidaczniają wyraźny rozwój koncepcji, której poszczególne zagadnienia na różnych etapach odgrywały pierwszoplanową rolę. Wzbogacały całokształt filozofii myślicielki, ale nie zmieniały zasadniczych ram myśli wyznaczonych realizacją głównego zadania, które Tymieniecka postawiła swojej międzynarodowej działalności naukowej - krytycznej recepcji klasycznej fenomenologii. Owo zadanie Tymieniecka wypełniała na kanwie interdyscyplinarnych konfrontacji fenomenologii Edmunda Husserla ze wszystkimi dziedzinami nauki, ze sztuką i z teologią oraz $\mathrm{w}$ polemice $\mathrm{z}$ fenomenologią Romana Ingardena. Celem filozof było, jak można sądzić, zdemaskowanie idealizmu w każdej jego postaci i utorowanie drogi realizmowi, który „przywróci” fenomenologii empirię ${ }^{2}$.

Jest zatem ze wszech miar uzasadnione, by twórczość Tymienieckiej rozpatrywać jako działalność fenomenologiczną oraz - rzec można - oryginalnie kontrowersyjną. I rzeczywiście, twórczość tej humanistki znana jest w filozoficznym środowisku naukowym głównie jako koncepcja fenomenologii życia i ludzkiej kondycji twórczej. Całokształt tej twórczości, który można ująć ogólnym sformułowaniem „filozofia życia”, stanowi jednak myśl, która wymyka się jednoznacznemu określeniu - jest zarazem koncepcją fenomenologii egzystencjalnej oraz egzystencjalizmu fenomenologicznego, przy czym bez uwzględnienia egzystencjalistycznej (metafizycznej) wizji, którą

1 Anna-Teresa Tymieniecka (1923-2014) mieszkała w Vermont (USA). W latach 19451947 studiowała na Uniwersytecie Jagiellońskim (była studentką Romana Ingardena), następnie na Sorbonie (1951), później była doktorantką w szwajcarskim Fryburgu (1952), od 1954 roku pracowała jako nauczyciel akademicki i pracownik naukowy w USA (Berkeley, Yale, Nowy Jork). W 1968 roku założyła serię wydawniczą Analecta Husserliana. The Yearbook of Phenomenological Research, której była redaktorem naczelnym. Była również inicjatorką powstania czasopisma „Phenomenology Information Bulletin” (od 1985 roku pod tytułem „Phenomenological Inquiry. A Review of Philosophical Ideas and Trends”). A. Szymaniak: Anna Teresa Tymieniecka. W: Encyklopedia filozofii polskiej. T. 2: M-Ż. Kom. nauk. A. Maryniarczyk et al. Polskie Towarzystwo Tomasza z Akwinu, Lublin 2011, s. 759.

${ }^{2}$ Spór o realizm (z idealizmem), wszczęty przez Romana Ingardena, który odnosił się do fenomenologii Edmunda Husserla, zainspirował Tymieniecką do podjęcia próby wykazania, że zachowanie ważności empirii w badaniach fenomenologicznych jest konieczne. Tymieniecka zwróciła uwagę na ten problem już w swojej pracy doktorskiej, która została wydana w języku francuskim w Paryżu w 1957 roku nakładem wydawnictwa Aubier pod tytułem: Essence et existence. Étude à propos de la philosophie de Roman Ingarden et de Nicolai Hartmann. 
ta filozof kreuje, a która wyraźnie odwołuje się do założeń naturalizmu, choć jednocześnie odżegnuje się od skrajności witalizmu, jakakolwiek próba określenia badań naukowych Tymienieckiej wydaje się niepełna.

Trudność jednoznacznego określenia filozofii myślicielki ma szczególnie znaczenie dla zagadnienia Boga, które stanowi punkt wyjścia i dojścia jej egzystencjalistycznych rozważań. Rozważania te od początku determinuje przekonanie, że filozofię należy uprawiać w ścisłym związku z pytaniem o sens ludzkiego życia, a życie - interpretować w kontekście kosmologicznych praw natury, które kierują jego ewolucyjnym rozwojem. Człowiek tutaj to swego rodzaju monada, jak w filozofii Leibniza, ze wszystkimi następstwami monadyczności, jak współistnienie z innymi monadami, bycie mikrokosmosem, a jednocześnie nieredukowalną do niczego i nikogo indywidualnością oraz, w pewnym zakresie, również samotnością. Myśl Tymienieckiej zakłada współistnienie tego, co wspólne, z tym, co indywidualne, i ich wzajemny, konstruktywny wpływ. W związku z tym zakłada także wzajemne przenikanie się tego, co uniwersalne, i tego, co szczegółowe (empiryczne). Filozof wielokrotnie podkreślała, że świadomość transcendentalna, która stanowi centrum fenomenologii Husserla, nastręcza szeregu problemów, z którymi nie poradził sobie sam jej twórca, nawet $\mathrm{z}$ zastosowaniem fenomenologicznej metody ${ }^{3}$. Pisała: „ani logika, ani jakakolwiek dedukcyjna nauka nie może doprowadzić do ostatecznego poznania świata i człowieka. [...] Dedukcyjna metoda operuje na wysokim poziomie abstrakcji; tak wysoko, że nie może uchwycić mniej abstrakcyjnych znaczeń z ich odniesieniem do konkretnych danych doświadczenia"4.

Świadomość transcendentalna leży w oddaleniu, a nawet w nieprzekraczalnym oddzieleniu od świata życia jako świata przyrody. Rozpatrywanie życia, także ludzkiego, w kontekście praw przyrody, tak jak to czyniła Tymieniecka, oznaczało ukłon w stronę nauk przyrodniczych. Nie bez racji są zatem ci niektórzy badacze fenomenologicznej myśli Tymienieckiej, którzy skłonni są uznać jej stanowisko za pewną postać witalizmu. Ona sama jednak zaprzeczała, jakoby tak było, podkreślając jednocześnie, że nie wiemy, o co ostatecznie toczy się "gra życia"s, co będzie nam dane lub co osiągniemy po jego ziemskim ustaniu. Nie wiemy także, co było

${ }^{3}$ Niekonkluzywność koncepcji Husserla wynikała z nieskończonego procesu konstytutywno-poznawczego „Ja fenomenologizującego”. Zob. P. Łaciak: Eugena Finka rozumienie Ja transcendentalnego. „Folia Philosophica” 2011, vol. 29, s. 213-220.

${ }^{4}$ A.T. Tymieniecka: Phenomenology and Science in Contemporary European Thought. Farrar, Straus and Cudahy, New York 1962, s. 4. Jeśli nie podano inaczej, cytaty w przekładzie autorki artykułu.

${ }^{5}$ L.P. Torjussen, J. Servan, S. Andersen Øyen: An Interwiew with Anna-Teresa Tymieniecka [August 27, 2008, Bergen, Norway]. Pobrano z: http://www.phenomenology. org/images/Interview-A-T-Tymieniecka-27-August-2008.pdf [30.01.2021], s. 5. 
jej bezpośrednim początkiem - prapoczątkiem. Pozostaje przeczuwanie Transcendencji $\mathrm{w}$ ramach fenomenologii życia, przez co należy rozumieć, że życie ma swoje źródło w naturze, lecz jego rozwój nie sprowadza się wyłącznie do procesów biologicznych. Rozwój życia to fenomenologia, to ontopojeza - dynamiczny, ale przede wszystkim twórczy proces samorozwoju życia napędzany nie tylko naturalnymi, immanentnymi siłami i energiami, lecz także metafizycznym potencjałem logosu życia i twórczej wyobraźni ${ }^{6}$. Życie nie składa się z szeregu przypadków, które wystąpiły w przyrodzie, jakkolwiek przypadek stanowi nieodłączny czynnik ewolucji biologicznej. Życie jest wynikiem rozumnego (zachodzącego przy udziale rozumu i wyobraźni), sensownego i celowego rozwoju, którego finałem ma być zrealizowanie przez człowieka transnaturalnego przeznaczenia ludzkiego ducha ${ }^{7}$. O źródłach imaginatio creatrix i logosu życia Tymieniecka nigdzie się jednoznacznie nie wypowiedziała, wzmiankowała jedynie, że wszelkie dywagacje na ten temat leżą poza kompetencjami filozofii. Uznała jednak, że należy domniemywać istnienia i działania tych sił. Najistotniejsze dla tej koncepcji jest przeświadczenie, że ontopojetyczność życia najpełniej wyraża się $\mathrm{w}$ formie ludzkiego życia, które $\mathrm{z}$ jednej strony wyrasta ze świata przyrody, a z drugiej - za sprawą twórczej kondycji człowieka dąży do uniezależnienia się od przyrody i uwolnienia ducha ludzkiego od jej uwarunkowań. Innymi słowy, ewolucyjność (resp. postępowość) samorealizacji ontopojezy życia polega na wyznaczaniu horyzontu autentycznej wolności człowieka, która tylko pośrednio jest wolnością od przyrody, bezpośrednio zaś - wolnością ku Transcendencji (Sacrum, Boskości, Nieuwarunkowanemu, Wszystkoobejmującemu), co w ogóle jest istotą transnaturalnego powołania i przeznaczenia człowieka.

${ }^{6}$ Por. A.T. Tymieniecka: Impet $i$ równowaga $w$ życiowych strategiach rozumu. Przeł. M. Wiertlewska. T. 1. [Logos $i$ życie. Ks. 4]. Wydawnictwo Nauka i Innowacje, Poznań 2014, s. 250, 303.

7 A.T. Tymieniecka: Życie w petni logos. Ks. 1: Metafizyka Nowego Oświecenia. Przeł. M. Wiertlewska. Wydawnictwo Poznańskie, Poznań 2011, s. 26. 


\section{Wielka Metamorfoza}

Tymieniecka określiła ewolucyjny proces rozwoju życia, w toku którego wyłania się także życie ludzkie, mianem Wielkiej Metamorfozy ${ }^{8}$. Jej początek „zlokalizowała” w tak zwanej matrycy przyrody - w źródle wszelkiego życia. To łono życia stanowi pierwotny rezerwuar ze wszystkimi zasobami niezbędnymi do tego, by życie mogło się rozwinąć i ewoluować. Są tam również siły, energie, dynamizmy, wirtualności oraz prawa kierujące ewolucją przyrody ${ }^{9}$ - od stanu prebiotycznego, poprzez jej ożywione formy: począwszy od form najprostszych, jednokomórkowych, przez organizmy tkankowe roślinne i zwierzęce, aż do końcowego etapu - gatunku ludzkiego. Nie jest to jednak ewolucyjna wizja żywcem wyjęta $\mathrm{z}$ teorii Karola Darwina, gdyż elementem niezbędnym do zrozumienia koncepcji Tymienieckiej jest obecność wspomnianego łona życia, a w nim logosu życia (rozumu rozumów, sensu wszystkich sensów) oraz twórczej wyobraźni z ich dominującą nad wszystkimi innymi elementami życiotwórczymi mocą. Logos życia i twórcza wyobraźnia są tymi czynnikami, które nadają dynamikę i kierunek ewolucji świata i życia ${ }^{10}$. To one powodują, że ewolucja postępuje sensownie, by osiągać coraz bardziej złożone formy życia, utożsamianego zresztą przez Tymieniecką z formami świadomości ${ }^{11}$. Bo życie to świadomość. Ludzkie życie to samoświadomość w najpełniejszym, ziemskim wymiarze ${ }^{12}$. To samoświadomość, która nie tyle jest świadomością poznającą, ile świadomością tworzącą. To samoświadomość samoindywidualizująca ludzką egzystencję przez deszyfrację życia $\mathrm{w}$ akcie samointerpretacji człowieka żyjącego w jedności-ze-wszystkim-co-żyje ${ }^{13}$. Wyłonienie się w toku ewolucji ludzkiej kondycji twórczej z ludzkim umysłem (rozumem i wyobraźnią) rozpoczyna zupełnie nowy etap ewolucji całego uniwersum, którego człowiek do końca życia pozostaje integralną częścią, elementem, który równocześnie w sposób

8 Ibidem, s. 372.

9 Ibidem, s. 21-22, 74.

${ }^{10}$ Ibidem, s. 74, 85-87. Zob. także A.T. Tymieniecka: Impet $i$ równowaga $w$ życiowych strategiach rozumu..., s. 350-351.

${ }^{11}$ A. Tymieniecka: The Human Condition within the Unity-of-Everything-there-is-Alive and its Logoic Network. W: Logos of Phenomenology and Phenomenology of the Logos. Book 2: The Human Condition in-the-Unity-of-Everything-there-is-alive. Individuation, Self, Person, Self-determination, Freedom, Necessity. Ed. A.T. Tymieniecka. [Analecta Husserliana. Vol. 89]. Springer, Dordrecht 2006, s. XV-XVI. http://link.springer.com/ book/10.1007/1-4020-3707-4/page/2 [dostęp: 17.11.2012].

12 A.T. Tymieniecka: Impet $i$ równowaga w życiowych strategiach rozumu..., s. 296-302.

13 A.T. Tymieniecka: Życie w petni logos..., s. $73 \mathrm{i}$ in. 
istotny wyróżnia się spośród wszystkich pozostałych elementów uniwersum. Kurs logosu życia ulega odwróceniu, gdyż witalne siły przyrody w człowie$\mathrm{ku}$ słabną ${ }^{14}$. Na tym jednak właśnie polega dążenie ku Boskości, transcendowanie przez człowieka swoich przyrodniczych uwarunkowań. Wówczas zaczynają się kształtować te sensy życia ludzkiego, które z biologicznym przetrwaniem nie mają bezpośredniego związku. Destrukcja, która dotyka witalnego wymiaru życia, okazuje się konstruktywna dla jego wymiaru społecznego, moralnego, a w końcu sakralnego. Wszystkie te wymiary łączą się $\mathrm{z}$ sobą, zazębiają i płynnie przechodzą jeden w drugi ${ }^{15}$. Wielka Metamorfoza nieustannie trwa, co jest zasługą człowieka.

Tak można streścić ujęcie przebiegu ewolucji życia przez Tymieniecką. Dodatkowo w jej koncepcji na ewolucję składają się nie tylko momenty konstrukcji, lecz także destrukcji (co potwierdza obserwacja świata przyrody, jak również nasza archeologiczna wiedza na temat różnych kultur ludzkich). Nie przeczy to jednak postępowości ewolucji w perspektywie życia jako całości i życia ludzkiego w szczególności. Przyrodniczy postęp ewolucyjny jest potwierdzony obecnością gatunku ludzkiego z jego wyjątkowo rozwiniętym układem nerwowym. Postęp kulturowy zaś to już wyraz twórczej kondycji człowieka, ludzkich twórczych dążeń, ale wyrosłych na podłożu naturalnym. To one nadają dalszemu biegowi ewolucji szczególną dynamikę, sprzyjają szybkiemu zachodzeniu w jej toku zmian, a przede wszystkim - wyłonieniu się niespotykanych w świecie przyrody aspektów, które dla samego świata przyrody wydają się zupełnie zbędne. Mowa o aspektach społeczno-moralnym (a nie wyłącznie społecznym, który w naturze dość często występuje) oraz sakralnym - wiodącym ewolucję życia ku Transcendencji, ku Bogu i ku realizacji transnaturalnego przeznaczenia człowieka.

Tak zarysowana wizja fenomenologii życia i ludzkiej kondycji twórczej, zgodnie z intencją autorki tej koncepcji, ma na celu przedstawienie świadomości transcendentalnej w sposób całkowicie odmienny od tego, jaki zaproponował Edmund Husserl ${ }^{16}$. Świadomość transcendentalna, jako twórcza samoświadomość człowieka, jest tutaj warunkiem człowieczeństwa, które nie jest jednak czymś już gotowym i danym, ale zadanym. Człowieczeństwo jest swego rodzaju drogą, którą człowiek kroczy, żyjąc w jedności-ze-wszystkim-

14 Ibidem, s. 372.

15 Ibidem, s. 298-350.

${ }^{16}$ Zdaniem Tymienieckiej świadomość transcendentalna w fenomenologii Husserla jest pozbawiona twórczego dynamizmu, który nie może zostać zastąpiony jej aktami poznawczo-konstytuującymi. W koncepcji Husserla cała rzeczywistość jawi się jako skostniały konstrukt. A.T. Tymieniecka: Zagadnienia filozoficzne naszych czasów. Akt twórczy człowieka jako ostateczne źródło racjonalności. W: Prace Kongresu Kultury Polskiej. Filozofia polska na obczyźnie. Red. W. Strzałkowski. T. 6. Polskie Towarzystwo Naukowe na Obczyźnie, Londyn 1987, s. 70. 
-co-żyje, jednocześnie transcendując swoje witalne uwarunkowania ku nadawaniu życiu ponadwitalnego i poprzezwitalnego sensu: intelektualnego, społeczno-moralnego i wreszcie sakralnego. To jest nadal proces Wielkiej Metamorfozy, który wraz z wyłonieniem się ludzkiej, twórczej kondycji osiąga punkt kulminacyjny. Każdy etap tego procesu zachodzi w samym centrum ludzkiej duszy, gdyż, jak słusznie zauważa Monika Maria Kowalczyk, „za Husserlem uznaje ona [Tymieniecka - M.M.] duszę za doznaniowe (passional) podłoże sił ożywiających mechanizmy fizjologiczne człowieka, a także czynnik stanowiący rację tożsamości jednostki’”17. Jest to proces, który można utożsamić z narodzinami i rozwojem ludzkiego ducha w „samym sercu duszy"18 (animus) ku absolutnej wolności, dokonujący się: po pierwsze, poprzez ludzką aktywność na kanwie filozofii i nauki oraz wznioślejszej od niej i bogatszej w udział wyobraźni sztuki, po drugie, realizację życia społecznego $\mathrm{w}$ zgodzie z moralnymi zasadami ufundowanymi na miłości do (drugiego) człowieka, po trzecie, w poszukiwaniach Boskości w człowieku. Co się tyczy tego ostatniego, to zarówno ścieżka społeczno-moralna, jak i ścieżki intelektualna oraz artystyczna - sądziła Tymieniecka - wiodą ku realizacji ludzkiego życia w perspektywie Transcendencji. Ścieżki te tworzy wyobraźnia, a drogowskazy na nich „stawia” rozum.

Autorka omawianej tutaj koncepcji fenomenologii życia podkreślała, że chociaż intelektualny, społeczno-moralny i sakralny wymiar życia nadają swoistość ludzkiemu sposobowi istnienia w jedności-ze-wszystkim-co-żyje, owej swoistości nie można ujrzeć bez uwzględnienia faktu zanurzenia życia ludzkiego w świecie przyrody. Ale jest to szczególne, ludzkie zanurzenie, dzięki któremu w konfrontacji $\mathrm{z}$ empirią rodzi się $\mathrm{w}$ człowieku największe życiowe pragnienie i tęsknota. Tymieniecka pisze: „Za sprawą sięgającego samych naszych trzewi pragnienia nawiązania kontaktu, ponownego włączenia się $\mathrm{w}$ źródło naszej prawdziwej natury i odnalezienia się w uczestnictwie we Wszystkim, dusza zrzuca z siebie jedną po drugiej wszystkie przemijające, przygodne i arbitralne warstwy swego jestestwa, pozostawiając nieosłonięte doświadczenie ogołoconego ja. To, co pozostaje, oczekuje Wszystkoobejmującego, oczekuje komunii z Wszystkoogarniającym i Bezkresnym, oczekuje spotkania z Boskością w swoim wnętrzu"19.

Wedle niektórych interpretatorów tej koncepcji - co warto tym miejscu podkreślić - Tymieniecka chciała wyrazić przekonanie, że pragnienie Boga jest wyrazem odwiecznej niezgody człowieka na przemijalność życia i pożądania jego wiecznego trwania. W tym kierunku zmierza Nadia Delle

${ }_{17}$ M.M. Kowalczyk: Anny-Teresy Tymienieckiej fenomenologia duszy. „Horyzonty Edukacji” 2007, nr 6 (11), s. 218.

${ }_{18}$ Zob. ibidem, s. 217.

19 Zob. A.T. Tymieniecka: Życie w petni logos..., s. 376-377. 
Site, która wskazuje na perspektywy, w jakich fenomenolog zaprezentowała ludzką kondycję twórczą ${ }^{20}$. Wydaje się jednak, że to wniosek nieco zbyt daleko idący, zwłaszcza że sugerowałby ewentualną próbę ucieczki człowieka od egzystencji w doczesności. Tymieniecka $\mathrm{w}$ swoich publikacjach nie wypowiadała się w sposób, który by jednoznacznie wskazywał na podobny tok myślenia. Owszem, człowiek intuicyjnie przeczuwa, że ponad życiem witalnym istnieje możliwość spotkania z Transcendencją, z Bogiem, przeczuwa również związaną z tym perspektywę absolutnej wolności, a także zapewne - wiecznego szczęścia. Życie witalne ma jednak dla człowieka wartość, z której ten świadomie - najczęściej - nie rezygnuje. Wiedziona optymizmem co do możliwości wykuwania przez człowieka własnego losu, który to optymizm oczywiście niekonieczne należy podzielać, Tymieniecka chciała raczej przekazać, że człowiek nie ucieka od życia witalnego, lecz wykorzystuje jego potencjał w celu rozwinięcia duchowych wymiarów swojej egzystencji, a tym samym zbliża się do Boga. Doświadczenie opisane $\mathrm{w}$ przytoczonym cytacie wydaje się wręcz doświadczeniem mistycznym, ale takim, w którym dusza nie rezygnuje $\mathrm{z}$ doczesnego życia, nie zawiesza go, by zjednoczyć się z Boskością w Prawdzie, w Dobru i Pięknie, lecz w pełni wykorzystuje doświadczenie życia. Ścieżka ku Boskości, ku Nieuwarunkowanemu biegnie przez ludzkie, osobowe wnętrze (przez myśli człowieka, jego wyobraźnię, uczucia i emocje, a nawet pierwotne popędy i instynkty), w którym odzwierciedla się, niczym w monadzie, cały wszechświat.

Tak rozumiana fenomenologia, jako fenomenologia życia, ma być drogą wyjścia poza uwarunkowania ludzkiej kondycji, poza to, co dążenia człowieka ku Transcendencji ogranicza, choć ich nie wyklucza. Otwiera możliwość pytań o wolność, szczęście, sprawiedliwość, zemstę, dobro i zło - pytań, które transcendują ograniczenia natury i stanowią wyraz elan ducha czującego się powołanym do wyższego przeznaczenia ${ }^{21}$. Tymieniecka pisze: „Te pytania są samym rdzeniem naszego zagadnienia absolutnej prawdy, przez samą swą naturę wychodzą poza uwarunkowania i rozum i mogą być sensownie formułowane oraz ponownie zadawane tylko wewnątrz kondycji ludzkiego świata i natury, z której wypływają"22.

${ }^{20}$ Zob. N. Delle Site: The Human Condition in the Cosmological, Metaphysical and Anthropological Perspective of Anna Teresa Tymieniecka. W: Reason, Life, Culture. Part II. Ed. A.T. Tymieniecka. [Analecta Husserliana. Vol. 40]. Springer, Dordrecht 1993, s. 55. http://link.springer.com/chapter/10.1007/978-94-011-1677-0_4 [dostęp: 22.09.2014].

${ }^{21}$ A.T. Tymieniecka: The Fulness of the Logos in the Key of Life. Book 2: Christo-Logos: Metaphysical Rhapsodies of Faith (,,Itinerarium mentis in deo”). [Analecta Husserliana. Vol. 111]. Springer, Dordrecht 2012, s. 74-76. https://doi.org/10.1007/978-94-007-2257-6.

${ }^{22}$ Ibidem, s. 76. 


\section{$\mathrm{Ku}$ Transcendencji}

Tymieniecka - potwierdzając pierwotne założenie fenomenologii życia i ludzkiej kondycji twórczej, że filozofia/fenomenologia wypływa wprost z ludzkiego życia, z centrum ludzkiej duszy, jest naturalną konsekwencją życia i nie wymaga żadnej specyficznie opracowanej metody, a ,jedynie" intuicyjnego podążania za spontanicznie odczuwanym przez człowieka powołaniem do przekraczania zewnętrznych i wewnętrznych ograniczeń natury ku absolutnej wolności w obliczu Transcendencji - konstruuje wizję egzystencji. Wizja ta, chociaż z założenia uniwersalna, ujawnia wpływy myśli chrześcijańskiej. Della Site, która podsumowuje stanowisko Tymienieckiej w kwestii ludzkich zdolności poznawczych, konkluduje, że ich ograniczone możliwości jawią się człowiekowi tym wyraźniej, im więcej rozumie on i poznaje. W ten sposób człowiek zyskuje fundamentalne przekonanie, że jedynie Bóg zdolny jest do poznawania absolutnego, a jakakolwiek ludzka próba odkrycia kryteriów Prawdy, którymi On się kieruje, i zrozumienia Jego punktu widzenia, skazana jest na porażkę, ponieważ wynika z wąskich ram naszego intelektu, z omylności i niewystarczalności naszej świadomości ${ }^{23}$. Tymieniecka generalnie zapewne zgodziłaby się z tym twierdzeniem, samo w sobie wydaje się ono jednak wprowadzać do dyskusji elementy odsyłające do teologii i wykraczające poza ścisły/naukowy dyskurs filozoficzny. Filozof, tak jak odżegnywała się od witalizmu w swoich rozważaniach, podobnie odnosiła się do ewentualnych podejrzeń o wchodzenie przez nią $\mathrm{w}$ kompetencje teologii ${ }^{24}$. Poza tym stanowisko Tymienieckiej w kwestii niewystarczalności poznawczej ludzkiej świadomości winno, oprócz odniesienia do intelektu, zawierać także odesłanie do wyobraźni: Boskość nie jest tym, co moglibyśmy sobie wyobrazić, dlatego jej „ogarnięcie” wyłącznie rozumem jawi się jako niemożliwe ${ }^{25}$. Ani zatem rozum, ani wyobraźnia ludzka nie sięgają samego Nieuwarunkowanego, gdyż dusza do ostatnich chwil działania fizjologicznych procesów w organizmie człowieka pozostaje w uwarunkowaniach przyrodniczych, to tam ludzki duch ma swoje korzenie. Podobnie zresztą nie możemy sobie wyobrazić ogromu stworzenia, w którym pierwotnie partycypujemy, a które - jak uważała Tymieniecka - nie wyczerpuje się w życiu na planecie Ziemia ${ }^{26}$.

${ }^{23}$ Zob. N. Delle Site: The Human Condition..., s. 55-56.

${ }^{24}$ Zob. L.P. Torjussen, J. Servan, S. Andersen Øyen: An Interwiew with Anna-Teresa Tymieniecka..., s. 7.

${ }^{25}$ Zob. A.T. Tymieniecka: The Fulness of the Logos in the Key of Life..., s. 77-78.

${ }^{26}$ A.T. Tymieniecka: Życie w petni logos..., s. 376. 
Nieuwarunkowany jawi się zatem tutaj jako horyzont, w kierunku którego zwraca się ludzka dusza i ludzki umysł: rozum i wyobraźnia. Jest to horyzont bardzo wyraźnie wewnętrznie, intuicyjnie przeczuwany przez człowieka, nawet jeśli jest to horyzont nieskończenie odległy. Tymieniecka przywołuje słowa świętego Augustyna: „Kochaj Boga i czyń, co chcesz”27, które przez wzgląd na założone w koncepcji fenomenologii życia i ludzkiej kondycji twórczej projektowanie przez człowieka przyszłości własnej i świata, życia w sensie moralnym i sakralnym, stają się bardzo wymowne. Życie i cele człowieka składają się na Wielką Grę Stworzenia i Zbawienia - twierdzi Tymieniecka. To dialektyka nieskończonego i skończonego, kompletności i fragmentaryczności, tego, co trwałe, z tym, co zniszczalne, uwarunkowania i tęsknoty za Odkupieniem ${ }^{28}$. Ta gra to walka o życie, o przetrwanie. Mimo że użyty jest tutaj język nauk przyrodniczych, w którym „przetrwanie” odnosi się do sfery biologicznej, termin ,przetrwanie” oznacza przede wszystkim duchowy wysiłek człowieka, którego celem jest wzniesienie życia na pułap transcendujący empirię i osiągnięcie poziomu świadomości transcendentalnej po to, by urzeczywistnić możliwość życia wiecznego, jaką daje obietnica spotkania Nieuwarunkowanego. „Właściwie uświadamianie sobie ostateczności pokrywa się z walką o życie"29 - pisze Tymieniecka.

Owo heroiczne zadanie człowiek podejmuje wytrwale każdego dnia czasami doskonale zdaje sobie $\mathrm{z}$ tego sprawę, a innym razem po prostu poddaje się prądowi życia (chociaż trafniejsze jest określenie „rwąca rzeka życia”, bo to nurt, którego nie można zatrzymać i z którego nie można się bezkarnie wydostać, jeśli nie chce się stracić życia) zaczyna w końcu ujawniać swoją naturę, która mobilizuje go do samorealizacji - do uruchomienia twórczych sił. Samorealizacja polega na takim ukierunkowaniu przez człowieka drogi swojego życia, by zyskało ono inne jeszcze niż tylko witalny sensy. W koncepcji autorstwa Tymienieckiej owa droga usłana jest cierpieniem. Człowiek, doświadczając swojej kondycji, próbuje odnaleźć dla siebie ,punkt odpoczynku”, ,wytchnienia” w dynamicznie rwącej rzece $\dot{z ̇ y c i a}^{30}$. Za dynamiką rzeczywistości podąża zmiana powodowana permanentnym poruszeniem wszystkich elementów tej rzeczywistości. I to owa zmienność rzeczywistości, a nie sam fakt doczesności, jawi się człowiekowi jako źródło cierpienia.

Tymieniecka powołuje się na obserwacje z życia. Pisze o noworodkach, które zaraz po narodzinach potrafią manifestować niezadowolenie, czy wręcz nieokreślony ból wywołany gwałtowną zmianą ich pozycji z horyzontalnej

\footnotetext{
${ }^{27}$ Cyt. za: A.T. Tymieniecka: The Fulness of the Logos in the Key of Life..., s. 78.

${ }^{28}$ Ibidem, s. 79.

${ }^{29}$ Ibidem.

${ }^{30}$ Ibidem, s. 87, 89.
} 
na wertykalną; nowo narodzone dziecko manifestuje to całym swoim ciałem. Filozof przytacza jeszcze inne przykłady określonego zachowania się noworodków w obliczu różnorodnych zmian zachodzących w ich najbliższym otoczeniu - te zachowania zdradzają coś, co można zdefiniować jako cierpienie $^{31}$. Zapewne nie bez powodu myślicielka wybrała za przykład noworodki, gdyż w ich przypadku wpływy zewnętrzne: kulturowe, społeczne, nawet rodzinne, nie są jeszcze zbyt mocno ujawnione. Zachowanie nowo narodzonego dziecka ukazujące, w jaki sposób doświadcza ono swojego życia, będzie służyło eksplikacji najbardziej pierwotnych doznań, uczuć i przeżyć człowieka. Dlatego Tymieniecka uznała, że doświadczenie zmiany, podobnie jak doświadczenie powodowanego przez zmianę cierpienia, to de facto doświadczenie samej esencji życia. Ale ani zmiana, ani cierpienie nie oznaczają definitywnego rozpadu i końca życia, chociaż są odbierane przez człowieka jako zagrożenie - prowadzą przecież żywy organizm do nieuchronnej śmierci, obnażając jego zależność od praw i procesów przyrody oraz związanych z nimi ograniczeń. A mimo to człowiek angażuje się w dokonywanie zmian w obrębie świata i życia, nie dąży do zatrzymania procesu zmian, bo życie utożsamia $\mathrm{z}$ dialektyką przeciwieństw ${ }^{32}$.

Filozof w swoich rozważaniach o swoistości natury człowieka powołuje się także na klasyczny przykład Syzyfa ${ }^{33}$. Człowiek, podobnie jak Syzyf, realizuje swoje przeznaczenie $\mathrm{w}$ procesie destrukcji, która jednak otwiera pole konstruktywnej refleksyjności - daje możliwość dostrzeżenia, że droga dopełnienia i wypełnienia ludzkiego życia w Transcendencji, a tym samym osiągnięcia tak bardzo pożądanego „odpoczynku” (na szczycie góry) wymaga wysiłku i znoszenia cierpienia. Zgodnie $\mathrm{z}$ wizją filozof osiągnięciu Transcendencji sprzyja naturalne osłabienie sił witalnych. Dopiero osłabieni „odzyskujemy nieśmiertelny plan naszego życia, kreujemy nasze przeznaczenie" 34 - pisze. Jeśli człowiek nie podejmuje tej syzyfowej pracy, to jedynie dryfuje na falach rwącego potoku życia prosto ku „otchłani śmierci" ${ }^{35}$. W naszej codziennej walce budujemy coś, co wydaje się stabilizacją - podejmujemy próby okiełznania przyrody, na przykład rozwijamy różne formy opieki nad osobami starszymi. Działania te nie uchronią nas od konsekwencji upływającego czasu, ale mogą dawać poczucie, że nie jesteśmy bierni i nasze życie w coraz większej mierze zależy od nas ${ }^{36}$.

${ }^{31}$ Ibidem, s. 104-105.

32 A.T. Tymieniecka: The Human Condition in-the-Unity-of-Everything-there-is-alive and its Logoic Network..., s. XV-XVI.

${ }_{33}$ A.T. Tymieniecka: The Fulness of the Logos in the Key of Life..., s. 5, 51, 96.

${ }^{34}$ Ibidem, s. 64.

${ }^{35}$ Ibidem, s. 100, 181.

${ }^{36}$ Ibidem, s. 80, 90-91, 96-97. 
Jak podkreślała Tymieniecka, aspekt realizowania ludzkiego przeznaczenia i mozolnego pokonywania przez człowieka ograniczeń na drodze wiodącej ku Nieuwarunkowanemu jest istotny dla zrozumienia jedynej właściwej miary twórczości, która towarzyszy temu wysiłkowi. Twórczość człowieka nie może pozostawać bez miary i nie powinna zadowalać się byle jaką miarą. Twórczości człowieka potrzebna jest miara moralna. Myśl o tym była istotnym czynnikiem budującym przekonanie Tymienieckiej o barbarzyństwie współczesnej nam kultury, wynikającym z nieokiełznanego i niejednokrotnie „wyjętego" spod jakichkolwiek norm moralnych rozwoju technicznego i technologiczno-naukowego ${ }^{37}$.

Skoro w świecie przyrody króluje ruch i zmiana, to gdzie poszukiwać Nieuwarunkowanego - Boskości - Sacrum - Boga? Ludzkie duchowe wnętrze, w którym wyraża się cała specyfika i złożoność człowieka, również podlega poruszeniom i transformacjom. Właśnie przez tę zmienność, nieprzewidywalną i budzącą cierpienie, wiedzie jednak droga ku Transcendencji. „Ja”, do którego winien się zwracać człowiek dokonujący wyboru określonej ścieżki w obrębie tej drogi, nie może być rozumiane jako „Ja czyste”, o którym pisał Husserl, a wcześniej Kartezjusz - uważała filozof. Twierdziła, że „Ja czyste” stanowi jedynie „Ja logiczne” - zasadę syntetycznej jedności wszystkich świadomościowych operacji człowieka, swoiste pole tożsamości na abstrakcyjnym, czysto racjonalnym poziomie. „Ja”, do którego zwraca się fenomenologia życia, to ,ja” realne, konkretne, takie, które żyje i samoindywidualizuje się w życiu, samointerpretuje się w nim w jedności-ze-wszystkim-co-żyje. To ,ja” twórcze i dynamiczne, swoją twórczością i dynamizmem konstytuujące siebie oraz zmieniające się „na własnych oczach”, które ,ubiera siebie we wszystkie jakościowe aspekty swoich operacji [świadomościowych - M.M.], [...] identyfikuje siebie bardziej z niektórymi z nich i mniej z pozostałymi" ${ }^{38}$. Taki sposób odnoszenia się człowieka do samego siebie, identyfikowania siebie i projektowania swojej przyszłości jest niepowtarzalny w świecie stanowiącym jedność-ze-wszystkim-co-żyje. Człowiek, gdy osiągnie pełnię rozwoju biologicznego, zwłaszcza centralnego układu nerwowego, oraz uzyska głęboką samoświadomość i refleksyjność, przeżywa swoje życie, analizuje je i dalej projektuje, coraz lepiej pojmując, że uwarunkowania przyrodnicze nie determinują go bez reszty, że rozpościera się przed nim możliwość życia w ogromnej mierze zależnego od jego własnych wyborów, chociaż nie jest to życie pozbawione cierpienia. A im więcej i głębiej człowiek zastanawia się nad swym istnieniem, tym więcej cierpienia dostrzega, tym bardziej cierpi i mocniej pragnie się od cierpienia uwolnić.

37 A.T. Tymieniecka: Życie w petni $\log o s . \ldots$, s. 12.

38 A.T. Tymieniecka: The Fulness of the Logos in the Key of Life..., s. 93. 
Mimo że sytuacja wydaje się paradoksalna, wcale taka nie jest. Twórczość nie boi się przeciwieństw, bo one rodzą napięcia jeszcze mocniej przynaglające do tworzenia. Tymieniecka przytacza w tym kontekście metaforę światła i cienia, w której światłem jest życie, a cieniem - cierpienie - jako konsekwencja życia, coś, co jest z nim związane ${ }^{39}$. Te, jak można sądzić, przeciwieństwa nie wykluczają się, ale uzupełniają, tworząc pewną całość. Im lepiej człowiek pojmie tę prawdę, tym bardziej wydajna będzie jego twórczość. W innym razie: „Zamiast wznosić się na skrzydle cierpienia $\mathrm{w}$ kierunku samoobejmującej egzaltacji, będzie tonął $\mathrm{w}$ bagnie braku znaczenia" $^{40}$ - pisze filozof.

\section{Konkluzja}

Wydaje się, że doświadczenie życia w Tymienieckiej fenomenologii życia i ludzkiej kondycji twórczej, jako doświadczenie najbardziej pierwotne i fundamentalne w przeżywaniu przez człowieka jego człowieczeństwa i wyrażaniu tego przeżywania w dokonywanych wyborach oraz działaniach - w akcie twórczym, realizuje w pełni swoje fenomenologiczne zadanie dopiero wówczas, gdy wątek aktu twórczego zostanie rozbudowany o aspekt ludzkiego cierpienia i tęsknoty za Transcendencją - Boskością - Nieuwarunkowanym, czy też po prostu - za Bogiem. Akt twórczy człowieka, na który składają się twory wyobraźni i wybory rozumu, to ontopojetyczna płaszczyzna stawania się życia ${ }^{41}$. Egzystencjalna wizja owego stawania się życia, którą opracowała myślicielka, jawi się jako konieczna dla zrozumienia jej koncepcji fenomenologii życia i ludzkiej kondycji twórczej podstawa, jako punkt odniesienia. Jak już napisano, w konstruowaniu tej wizji przez Tymieniecką doniosłą rolę odegrała nauka, szczególnie nauki przyrodnicze, ale także sztuka i religia oraz, co oczywiste, ich sposób pojmowania: jako wieloaspektowych prób zrozumienia przez człowieka sensu swojego życia i życia w ogóle. Próby te wyznaczają bieg ludzkiego życia i jego rozwój duchowy w wymiarze intelektualnym, społeczno-moralnym, a w końcu także sakralnym. Poszukiwania intelektualne pogłębiają wiedzę człowieka o zintegrowanym z życiem kosmosu ludzkim życiu i pierwotne przekonanie człowieka o zmienności rzeczy-

\footnotetext{
${ }^{39}$ Ibidem, s. 64-66.

${ }^{40}$ Ibidem.

${ }^{41}$ A.T. Tymieniecka: Życie w petni $\operatorname{logos} \ldots$, s. $28-29$.
} 
wistości i nieuchronności jego końca. Ta refleksja prowadzi do przeżywania cierpienia i potęguje tęsknotę człowieka za kimś, kto w podobny sposób doświadcza swojego życia. To zaś stanowi bezpośredni impuls do rozwijania więzi międzyludzkich i społeczno-moralnego logosu życia.

Tymieniecka pisze o ,świadku życia” jako ludzkim świadku cierpienia ${ }^{42}$. Nawet jeśli człowieka $\mathrm{z}$ drugą osobą łączą tylko trywialne poglądy, uczucia, emocje, ale ich treść jest jasna dla obu stron, buduje się „most” łączący ich świadomości - nić porozumienia, więź z drugim człowiekiem pozwalająca na „wspólne” doświadczanie życia i cierpienia w nim ${ }^{43}$. Spotkanie z ludzkim świadkiem życia jest istotnym momentem w rozwoju egzystencji. Niestety, nie może rozwiązać wszystkich problemów ani odpowiedzieć na wszystkie dręczące człowieka pytania. Być może nawet nie rozwiąże żadnego z problemów ani nie odpowie na żadne pytanie, a wręcz spotęguje wcześniejsze dylematy. „Przychodząc z niepowtarzalnego, jednostkowego splotu spraw życiowych - pisze Tymieniecka - nasz świadek nie jest w stanie przekroczyć barier indywidualizacji i swojego osobowego bycia, i całkowicie się z nami utożsamić" ${ }^{\prime 4}$. Droga samoindywidualizacji i samointerpretacji w egzystencji jest drogą samodzielną, a w przeważającej części także samotną. Możliwe są jednak sytuacje, gdy w naturalnym strumieniu życia tworzy się swego rodzaju luka, która pochodzi z samego jego wnętrza. Chociaż nadal pozostaje powiązana $\mathrm{z}$ naturalnymi procesami życia, już nie należy do jego linii rozwojowej. Stanowi moment podniesienia życia ludzkiego niejako na wyższy poziom. Tymieniecka pisze: „W tych unikalnych momentach odczuwamy siebie jako transcendujących nasze naturalne okowy i jesteśmy w stanie sięgnąć do jestestwa drugiego człowieka i dzielić z nim lub z nią ten prometejski moment prawdy, który otwiera dla nas inny horyzont niż ten związany z naszą ziemską, przyrodniczo uwarunkowaną kondycją" ${ }^{\prime 4}$. Rodzi się komunia dusz, a nie tylko więź społeczna. Człowiek poszukuje drugiego jestestwa w celu zakomunikowania mu własnej sytuacji życiowej, ale nie chodzi tylko o potrzebę otrzymania od niego krótkiej porady, jakiegoś wyjaśnienia obecnego położenia. Chodzi o to, by tę drugą osobę zaangażować we własny kurs życia, co implikuje niekończącą się debatę opatrzoną szeregiem wciąż na nowo stawianych pytań i wciąż na nowo podejmowanych prób odpowiedzi ${ }^{46}$.

Ta ostatnia myśl wydaje się spajać różnorodne wątki podejmowanych przez Tymieniecką rozważań $\mathrm{w}$ jedną całość. Wiele z tych wątków z pewnością ma kontrowersyjny charakter, a nawet rodzi niedosyt teoriopoznawczy.

\footnotetext{
${ }^{42}$ Ibidem, s. 351-355.

${ }^{43}$ A.T. Tymieniecka: The Fulness of the Logos in the Key of Life..., s. 55.

${ }^{44}$ A.T. Tymieniecka: Życie w petni logos..., s. 299.

${ }^{45}$ A.T. Tymieniecka: The Fulness of the Logos in the Key of Life..., s. 59.

${ }^{46}$ Ibidem, s. 56-57.
} 
Takie jest chociażby założenie, że życie ludzkie należy interpretować w kategoriach kosmologicznych i zarazem ewolucyjnych, wynikających z jego naturalnych, przyrodniczych korzeni. W tym podejściu mieści się przecież przekonanie o neurologicznym fundamencie świadomości, dzięki któremu można badać przynajmniej niektóre jej funkcje. Jako oczywiste i pewne w naukach przyrodniczych, stwierdzenie takie niekoniecznie jawi się jako w pełni uzasadnione w filozofii i fenomenologii. Faktem jest, że Tymieniecka ufała naukom przyrodniczym. Miała zapewne ku temu powody, których nie musimy przyjmować, ale jeden z nich wydaje się szczególnie godny uwagi. Tą racją jest nagląca, zdaniem filozof, potrzeba wprowadzenia fenomenologii na tory empirii, z których Husserl ją wyprowadził (a być może nawet wykoleił), by podtrzymać dotychczasową (Kartezjusz, Kant) przeciwstawność realizmu i idealizmu w sposobie wyjaśniania istnienia świata. Dla Tymienieckiej było priorytetem, aby pokazać i uzasadnić jedność wszechświata, ponieważ fenomenologia, jej zdaniem, nie może się ograniczać wyłącznie do badania samych możliwości poznania jako poznania, możliwości wiedzy i nauki, lecz powinna powracać do życia, z którego się wyłoniła. A to oznacza, że ma ona do zrealizowania zadanie o charakterze praktycznym i zarazem etycznym. Jest nim pokazanie jedności całego świata, w tym jedności świata i człowieka oraz jedności wszystkich ludzi. Ta jedność ma umożliwiać totalny dialog interdyscyplinarny, międzykulturowy, międzyreligijny, międzywyznaniowy, międzypokoleniowy, a nawet międzygatunkowy, ostatecznie eliminujący wszelkie konflikty. Jest to, jak się wydaje, idea bliższa romantyzmowi aniżeli oświeceniu, których charakter znamy z dziejów rozwoju ludzkiej kultury, ale nadal ufająca rozumowi, chociaż dająca te same prawa i autonomię także wyobraźni oraz, co tutaj bardzo istotne, wierze.

Nie ulega wątpliwości, że w zaproponowanym przez Tymieniecką kolejnym kroku w poszukiwaniach przez człowieka świadka życia pierwszeństwo zostaje przyznane myśli chrześcijańskiej. Jest to poszukiwanie Szczególnego Świadka, którego życie i śmierć mają pokazać, że nie wyczerpują się w kategoriach przyrodniczych. Dlatego filozof podkreślała, że doświadczenie zjednoczenia z Boskością zakłada wiarę w Chrystusa - człowieka i Boga jednocześnie - oraz w szczególny sens Jego życia, jakim było zbawienie ludzkości i otwarcie przed nią szansy na nieuwarunkowane życie w jedności $\mathrm{z}$ Bogiem ${ }^{47}$. Natomiast niedosyt $\mathrm{w}$ relacjach $\mathrm{z}$ innymi ludźmi często bywa efektem dostrzeżenia, że $\mathrm{w}$ relacjach tych dominuje przypominające szaleństwo poszukiwanie ziemskiej miłości, szczęścia, chwały, sławy, które miałyby dopełnić to życie ${ }^{48}$.

\footnotetext{
47 Zob. ibidem, s. 185-190.

48 Zob. ibidem, s. 4, 149, 195.
} 
Powstaje zatem pytanie: czy egzystencjalna wizja $\mathrm{i}$ związana $\mathrm{z}$ nią koncepcja fenomenologii życia i ludzkiej kondycji twórczej, tak wyraźnie nawiązujące do myśli chrześcijańskiej, są i muszą być ograniczone wyłącznie do odbiorców, którzy tę myśl przyjmują i na niej opierają swój światopogląd? Idea Nowego Oświecenia, idea twórczych dążeń człowieka i całej ludzkości do osiągnięcia absolutnej wolności w Transcendencji, idea życia w pełni logos, którą zaproponowała Tymieniecka, może, a nawet powinna być rozpatrywana jako uniwersalna, ogólnoludzka, generalnie - transgraniczna. Ma niezaprzeczalną wartość filozoficzną. Faktem jednak pozostaje, że wprowadzenie do tej idei elementów w oczywisty sposób odsyłających do chrześcijaństwa może skłaniać jej interpretatorów do podejmowania próby scharakteryzowania całokształtu tej myśli jako właśnie chrześcijańskiej. To zaś kłóci się ze stanowiskiem samej Tymienieckiej, która nie zgadzała się na sprowadzanie jej myśli, jako myśli filozoficznej, do jakiegokolwiek konkretnie określonego nurtu, czy to w filozofii, czy w innych naukach, oraz do identyfikowania tej myśli w odniesieniu do dogmatów jakiejkolwiek religii lub wiary ${ }^{49}$. Najwyraźniej filozof pragnęła zachować prawo, które w swojej koncepcji przyznała każdemu indywiduum ludzkiemu: prawo do twórczego aktu, w którym człowiek swobodnie wyraża to, na jak nieskończoną ilość sposobów przeżywa swoje życie i go doświadcza. A każdy z tych sposobów kieruje ludzkiego ducha zarazem ku niemu samemu i ku Boskości.

\section{Bibliografia}

Delle Site N.: The Human Condition in the Cosmological, Metaphysical and Anthropological Perspective of Anna Teresa Tymieniecka. W: Reason, Life, Culture. Part II. Ed. A.T. Tymieniecka. [Analecta Husserliana. Vol. 40]. Springer, Dordrecht 1993, s. 55-61. http://link.springer.com/chapter/10.1007/978-94-011-1677-0_4 [dostęp: 22.09.2014].

Kowalczyk M.M.: Anny-Teresy Tymienieckiej fenomenologia duszy. „Horyzonty Edukacji” 2007, nr 6 (11), s. 217-226.

Łaciak P.: Eugena Finka rozumienie Ja transcendentalnego. „Folia Philosophica” 2011, vol. 29, s. 205-224.

${ }^{49}$ Zob. L.P. Torjussen, J. Servan, S. Andersen Øyen: An Interwiew with Anna-Teresa Tymieniecka..., s. 6 . 
Szymaniak A.: Anna Teresa Tymieniecka. W: Encyklopedia filozofii polskiej. T. 2: $M-\dot{Z}$. Kom. nauk. A. Maryniarczyk et al. Polskie Towarzystwo Tomasza z Akwinu, Lublin 2011, s. 759-762.

Torjussen L.P., Servan J., Andersen Øyen S.: An Interwiew with Anna-Teresa Tymieniecka [August 27, 2008, Bergen, Norway]. Pobrano z: http://www. phenomenology.org/images/Interview-A-T-Tymieniecka-27-August-2008.pdf [30.01.2021].

Tymieniecka A.T.: Essence et existence. Étude à propos de la philosophie de Roman Ingarden et de Nicolai Hartmann. Aubier, Paris 1957.

Tymieniecka A.T.: The Fulness of the Logos in the Key of Life. Book 2: Christo-Logos: Metaphysical Rhapsodies of Faith (,,Itinerarium mentis in deo"). [Analecta Husserliana. Vol. 111]. Springer, Dordrecht 2012. https://oi. org/10.1007/978-94-007-2257-6.

Tymieniecka A.T.: The Human Condition within the Unity-of-Everything-there-isAlive and its Logoic Network. W: Logos of Phenomenology and Phenomenology of the Logos. Book 2: The Human Condition in-the-Unity-of-Everything-there-is-alive. Individuation, Self, Person, Self-determination, Freedom, Necessity. Ed. A.T. Tymieniecka. [Analecta Husserliana. Vol. 89]. Springer, Dordrecht 2006, s. XIII-XXXIII. http://link.springer.com/book/10.1007/1-4020-3707-4/ page/2 [dostęp: 17.11.2012].

Tymieniecka A.T.: Impet i równowaga w życiowych strategiach rozumu. T. 1. Przeł. M. Wiertlewska. [Logos i życie. Ks. 4]. Wydawnictwo Nauka i Innowacje, Poznań 2014.

Tymieniecka A.T.: Phenomenology and Science in Contemporary European Thought. Farrar, Straus and Cudahy, New York 1962.

Tymieniecka A.T.: Zagadnienia filozoficzne naszych czasów. Akt twórczy człowieka jako ostateczne źródło racjonalności. W: Prace Kongresu Kultury Polskiej. Filozofia polska na obczyźnie. Red. W. Strzałkowski. T. 6. Polskie Towarzystwo Naukowe na Obczyźnie, Londyn 1987, s. 67-78.

Tymieniecka A.T.: Życie w petni logos. Ks. 1: Metafizyka Nowego Oświecenia. Przeł. M. Wiertlewska. Wydawnictwo Poznańskie, Poznań 2011.

Magdalena Mruszczyk - adiunkt w Instytucie Filozofii na Wydziale Humanistycznym Uniwersytetu Śląskiego w Katowicach. Zajmuje się historią filozofii polskiej, głównie filozofii XX i XXI wieku, w szczególności jej zagadnienia$\mathrm{mi}$ antropologicznymi, etycznymi oraz epistemologicznymi. 